MARCIN FRENKEL

Uniwersytet Łódzki

ORCID: 0000-0003-1151-1968

marcin.frenkel@uni.lodz.pl

\title{
Polsko-amerykańska współpraca miast
} Analiza wyników badań ankietowych

\section{Contemporary cooperation of Polish and American cities}

The analysis of survey results

Słowa kluczowe: relacje Polska-USA, miasta, paradyplomacja, dyplomacja miast
Keywords:

Poland-USA relations, cities, paradiplomacy, city diplomacy 
Contemporary cooperation of Polish and American cities. The analysis of survey results

The article analyzes contemporary cooperation of Polish and American cities. Thus, it contributes to the research on the participation of non-state actors in the international relations. Currently, only 10 Polish cities conduct active cooperation with partners from the USA. These relationships focus on cooperation on issues such as culture, art, science and business. In most cases, these contacts were initiated by the Polish side, and they were based primarily on direct interpersonal contacts. Most partnership agreements were signed in the $1990 \mathrm{~s}$ and resulted from the collapse of the Soviet block and deep political changes in Poland. Currently, the main obstacles to the intensification of these local governments transatlantic relations is a weak American involvement, geographic distance and a lack of state support. 


\section{Wstęp}

W

ostatnich dziesięcioleciach obserwuje się w stosunkach międzynarodowych wzrost znaczenia podmiotów niepaństwowych. Do tego grona zalicza się m.in. globalne korporacje, organizacje pozarządowe (NGOs), a także samorządy, w tym miasta. Na skutek ewolucji współczesnej gospodarki krajów rozwiniętych - przejawiającej się m.in. zmniejszeniem udziału przemysłu oraz rolnictwa, a wzrostem udziału sektora usług (w tym zwłaszcza tych opartych na specjalistycznej wiedzy i zaawansowanych technologiach) wzmocnieniu ulega pozycja miast. To właśnie ośrodki miejskie oferują środowisko, w którym mogą funkcjonować przedsiębiorstwa tej nowej ekonomii. $\mathrm{Na}$ to przyjazne otoczenie składa się szereg czynników, takich jak obecność uczelni wyższych i instytutów badawczych (zapewniających zaplecze kadrowe oraz niezbędną dla dalszego rozwoju wiedzę, w tym know-how), ale też cała pozostała szeroko rozumiana infrastruktura miejska (obejmująca m.in. opiekę medyczną, transport publiczny, ofertę gastronomiczną, sportową, kulturalną, dostępność szkół i przedszkoli itd.) ${ }^{1}$. Do pewnego stopnia jest to też mechanizm samonapędzający się: obecność jednych przedsiębiorstw przyciąga inwestycje kolejnych firm, tworzących razem sieci kooperacji.

Stopniowo zwiększa się odsetek ludności świata żyjącej w miastach oraz wzrasta udział miast w wytwarzaniu globalnego $\mathrm{PKB}^{2}$. Proces ten, rzecz jasna, nie odbywa się na całym świecie w tym samym tempie i z tą samą intensywnością. Rozwojowi metropolii, które stały się centrami nowej gospodarki, towarzyszy upadek innych miast, które nie zdywersyfikowały na czas swojej strategii rozwoju, pozostając ośrodkami upadających gałęzi przemysłu (np. amerykańskie Detroit ${ }^{3}$ ). Niemniej w skali globalnej wzmocnienie pozycji miast jako niepaństwowych aktorów stosunków międzynarodowych jest zjawiskiem wyraźnie dostrzegalnym ${ }^{4}$. Coraz częściej

1 Patrz szerzej: D. Zawada, Walory użytkowe jako czynnik konkurencyjności miasta, „Prace Naukowe Uniwersytetu Ekonomicznego we Wrocławiu" 2012, nr 243, ss. 439-452.

2 M. Pieńkowski, K. Rybka-Iwańska, Miasta globalne $i$ ich znaczenie w polityce zagranicznej, „Studia Politologiczne” 2016, vol. 42, ss. 350-351. s. 347.

3 Patrz szerzej: Y. P. Lin, The fall of Detroit. A financial economist's point of view, "International Journal of Economics and Finance" 2014, vol. 6, no. 7.

4 Patrz szerzej: R. Tavares, Paradiplomacy. Cities and states as global players, Oxford University Press, New York 2016. 
fenomen ten staje się również przedmiotem badań naukowych. $\mathrm{Z}$ racji ograniczeń objętościowych niniejszego tekstu nie można wymienić wszystkich publikacji poświęconych tej tematyce, ale niewątpliwie warto tu odnotować chociażby prace: Benjamina Barbera (pt. Gdyby burmistrzowie rzqdzili światem $)^{5}$, Richarda Floridy (Narodziny klasy kreatywnej) ${ }^{6}$, Chadwicka F. Algera, (The world relations of cities. Closing the gap between social science paradigms and everyday human experience) ${ }^{7}$. Michele Acuto, (Global cities, governance and diplomacy) ${ }^{8}$, Jerzego J. Paryska (Duże miasta Europy $i$ ich rola $w$ procesie urbanizacji, rozwoju społeczno-gospodarczego i europejskiej integracji u schyłku XX wieku) ${ }^{9}$, a także pracę zbiorową pod redakcją Stijna Oosterlyncka (The city as a global political actor) ${ }^{10}$.

Rozwijające i bogacące się miasta od wieków były celem migracji ludności z regionów uboższych. To, co jednak odróżnia obecną sytuację od tej z przeszłości, to fakt, iż ośrodki miejskie konkurują między sobą o najlepiej wykształconą siłę roboczą na poziomie transgranicznym. W wielu krajach systemy edukacji nie nadążają bowiem z dostarczaniem na rynek pracy odpowiedniej ilości specjalistów, jakich wymaga gospodarka oparta na wiedzy.

W wyniku procesów migracyjnych metropolie w stosunku do reszty państwa charakteryzują się większą różnorodnością etniczną, religijną i kulturową, a także wyższym średnim poziomem wykształcenia mieszkańców ${ }^{11}$. Często towarzyszy temu powszechnie podzielana tolerancja wobec inności oraz światopoglądowy liberalizm, co wytwarza intelektualny

5 B. Barber, Gdyby burmistrzowie rządzili światem, przeł. H. Jankowska, K. Makaruk, Muza, Warszawa 2014.

6 R. Florida, Narodziny klasy kreatywnej, Narodowe Centrum Kultury, Warszawa 2011.

7 C. F. Alger, The world relations of cities. Closing the gap between social science paradigms and everyday human experience, "International Studies Quarterly" 1990, vol. 34(4).

8 M. Acuto, Global cities, governance, and diplomacy, Routledge, London 2016.

9 J. J. Parysek, Duże miasta Europy i ich rola w procesie urbanizacji, rozwoju społeczno-gospodarczego i europejskiej integracji u schyłku XX wieku, „Przegląd Geograficzny” 1995, T. LXVII, z. 3-4.

10 The city as a global political actor, eds S. Oosterlynck i in., Routledge, New York 2018.

11 M. Pieńkowski, K. Rybka-Iwańska, Miasta globalne..., ss. 350-351. 
„ferment" sprzyjający innowacyjności, na której bazuje współczesna ekonomia. Ma to też bezpośrednie przełożenie na wyniki wyborów do władz miejskich, w których często lepsze rezultaty niż w wyborach krajowych osiągają politycy liberalni bądź lewicowi. Dobrym przykładem jest tu Polska, gdzie prezydenci największych miast wywodzą się ze środowisk opozycyjnych wobec rządzącej krajem od 2015 r. partii o charakterze konserwatywno-narodowym.

Wspomniana więc rosnąca pozycja ekonomiczna miast i konkurencja między nimi już nie tylko o napływ inwestycji, ale również wykwalifikowanej siły roboczej, a także proces politycznej emancypacji - (a przynajmniej poczucie światopoglądowej odmienności w stosunku do władz krajowych) wpływają na ich ambicje w zakresie aktywności międzynarodowej. Również polskie miasta coraz intensywniej działają na szczeblu międzynarodowym, a proces ten od strony prawnej ułatwiła m.in. reforma samorządowa z 1990 r. $^{12}$, Konstytucja RP z 1997 r., Ustawa z dn. 15 września 2020 r. o zasadach przystępowania jednostek samorządu terytorialnego do międzynarodowych zrzeszeń społeczności lokalnych i regionalnych oraz ustawodawstwo Unii Europejskiej, której Rzeczpospolita jest członkiem od maja 2004 r. $^{13}$. Ten ostatni czynnik jest tu szczególnie istotny, gdyż wiąże się ze znaczącym wzrostem inwestycji zagranicznych w Polsce ${ }^{14}$, które pośrednio wzmocniły kondycję finansową samorządów, w tym miast ${ }^{15}$.

Bezpośrednią inspiracją do przeprowadzenia badań, których formą sprawozdania jest niniejszy artykuł, były dane zawarte w raporcie Polskiego

12 Reforma samorządowa z 1990 r. (Ustawa z dn. 8 marca 1990 r. o samorządzie gminnym) przywracała samorząd terytorialny na poziomie gminnym. W zakresie współpracy międzynarodowej gmin zastosowanie miał rozdz. 2 art. 7.1, pkt 20 oraz rozdz. 2 art. 18.2, pkt 12a.

13 M. Szewczak, M. Ganczar, P. Jaszczuk, Raport badawczy na temat "Współpraca międzynarodowa miast polskich", Narodowy Instytut Samorządu Terytorialnego, 2016 („Badania i raporty”, nr 3), ss. 3-6.

14 G. Ancyparowicz, Bezpośrednie inwestycje zagraniczne w Polsce po akcesji do Unii Europejskiej, „Zeszyty Naukowe SGGW - Ekonomika i Organizacja Gospodarki Żywnościowej" 2009, nr 77, s. 97.

15 Patrz szerzej: M. Ozga, Wpływ bezpośrednich inwestycji zagranicznych na dysproporcje międzyregionalne w Polsce, „Equilibrium. Quarterly Journal of Economics and Economic Policy" 2009, vol. 3, no. 2, ss.111-123. 
Instytutu Spraw Międzynarodowych, zatytułowanym Dyplomacja Samorzadowa. Efektywność i perspektywy rozwoju, autorstwa Adriany Skorupskiej ${ }^{16}$. Opracowanie to stanowi analizę współpracy polskich samorządów z partnerami zagranicznymi. Zawiera między innymi dane dotyczące aktywnych form współpracy w czasie powstawania raportu (2014 r.). Zidentyfikowano wtedy 453 aktywne relacje międzynarodowe polskich samorządów. Najwięcej tych kontaktów, co zrozumiałe w kontekście członkostwa Polski w Unii Europejskiej, odnotowano z partnerami europejskimi (400). Na drugim miejscu znalazły się podmioty samorządowe z Azji (37), a dopiero na trzecim miejscu partnerzy z Ameryki Północnej (8) - nieznacznie tylko wyprzedzając samorządy afrykańskie (6). Najmniejsza ilość relacji łączyła polskie samorządy z partnerami południowoamerykańskimi $(2)^{17}$. Biorąc pod uwagę - akcentowane na szczeblu rządowym - znaczenie stosunków polsko-amerykańskich ${ }^{18}$, zaskakująca jest ich bardzo niska intensywność na poziomie samorządowym - zwłaszcza gdy porównamy to do kontaktów na kierunku azjatyckim.

Podobny obraz współpracy polskich miast przyniósł raport autorstwa Marcina Szewczaka, Małgorzaty Ganczar i Pauliny Jaszczuk z 2016 r. W tym opracowaniu na 100 analizowanych przypadków zidentyfikowano jedynie sześć aktywnych polsko-amerykańskich relacji partnerskich na szczeblu miast ${ }^{19}$.

Obserwacje te pośrednio potwierdzają też wyniki badań prowadzonych w 2020 r. przez Joannę Ciesielską, Tomasza Kamińskiego i Michała Gzika z Katedry Azji Wschodniej na Wydziale Studiów Międzynarodowych i Politologicznych Uniwersytetu Łódzkiego, realizowanych w ramach (finansowanego przez Narodowe Centrum Nauki) projektu "Rola miast w polityce Unii Europejskiej wobec Chin"20. Łódzcy naukowcy skierowali

16 A. Skorupska, Dyplomacja samorządowa. Efektywność i perspektywy rozwoju, PISM, Warszawa, marzec 2015.

17 A. Skorupska, Dyplomacja..., s. 38.

18 Priorytety polskiej polityki zaǵranicznej 2012-2016, Ministerstwo Spraw Zagranicznych, Warszawa, marzec 2012, s. 14, dostępny w internecie [dostęp: 30 IV 2021]: <https:// www.bbn.gov.pl/download/1/9620/prpol.pdf >.

19 M. Szewczak, M. Ganczar, P. Jaszczuk, Raport badawczy..., s. 10.

20 Projekt nr 2019/33/B/HS5/01272, finansowany przez Narodowe Centrum Nauki w ramach programu OPUS-17. 
kwestionariusz badawczy do 63 największych polskich miast, otrzymując odpowiedź od 59 z nich. Niemal żadne z tych miast, nie zaliczyło strony amerykańskiej do grona dziesięciu najważniejszych partnerów zagranicznych. Wyjątek tu stanowiły jedynie dwa ośrodki, które przywołały relacje transatlantyckie: Toruń (z Philadelphią) oraz Gdynia (z Seattle). Dla porównania, blisko 45 proc. badanych miast nawiązało współpracę z miastami chińskimi i ocenia ją jako umiarkowanie ważną ${ }^{21}$.

Na relatywnie dużą intensywność relacji polskich samorządów z chińskimi partnerami wskazywał również raport Instytutu Spraw Publicznych (ISP) z 2012 r. pt. Wspótpraca zagraniczna polskich samorządów. Wnioski $z$ badañ ${ }^{22}$. W świetle tego opracowania Chiny są drugim po Europie, a Stany Zjednoczone trzecim najbardziej popularnym kierunkiem geograficznym, na którym dochodzi do nawiązywania współpracy na poziomie samorządów. Niemniej stopień powiązań lepiej obrazują liczby partnerstw niż pozycje w tym "rankingu”. I tak dla porównania najwięcej umów o współpracy polskie samorządy podpisały z partnerami z Niemiec (162) i z Ukrainy (112). Z Chinami natomiast współpracuje 25 , a z USA jedynie 18 samorządów ${ }^{23}$. Należy tu jednak podkreślić, iż raport ISP dotyczył nie tylko miast, ale również innych jednostek terytorialnych, takich jak gminy wiejskie, powiaty i województwa.

Warto w tym miejscu jeszcze nawiązać do najszerszego dotychczas badania współpracy zagranicznej polskich samorządów, zrealizowanego w 2009 r. przez Związek Miast Polskich w ramach projektu Komisji Europejskiej pt. „Europa dla Obywateli”. W przypadku tego przedsięwzięcia badawczego nie stosowano progów ograniczających liczbę badanych miast lub ǵmin, zarówno pod względem wielkości populacji, jak i aktywności współpracy, lecz objęto nim wszystkie powiaty w Polsce ${ }^{24}$. Na 3339 przebadanych powiatów 42 podjęły współpracę z samorządami amerykańskimi (tj. ok. 1,25\%). Dla porównania w przypadku partnerstwa ze stroną niemiecką liczba ta wynosiła aż 860 (tj. ok. 25,68\%), co natomiast jest szczególnie

21 Projekt nr 2019/33/B/HS5/01272....

22 A. Fuksiewicz, A. Łada, Ł. Wenerski, Wspótpraca zagraniczna polskich samorządów. Wnioski z badań, Warszawa 2012.

23 A. Fuksiewicz, A. Łada, Ł. Wenerski, Współpraca zagraniczna..., s. 23.

24 Wspótpraca miast partnerskich, Związek Miast Polskich, dostępny w internecie [dostęp: 30 IV 2021]: 〈https://www.miasta.pl/strony/wspolpraca-miast-partnerskich〉. 
ciekawe jedynie 16 (tj. 0,48\%) $)^{25}$ powiatów współpracowało z podmiotami z Chińskiej Republiki Ludowej ${ }^{26}$.

Autor niniejszego artykułu postawił sobie za cel zbadanie aktualnego stanu polsko-amerykańskich relacji na szczeblu miast (przede wszystkim zidentyfikowanie i zmapowanie sieci powiązań), w tym także odpowiedź na pytania dotyczące: ilości aktywnych partnerstw, czynników wpływających na skalę tego zjawiska, inicjatorów tej współpracy i jej przedmiotu, a także tego, jakie bariery napotyka (bądź jakie czynniki jej sprzyjają). Hipotezę badawczą, z jaką autor przystępował do pracy, stanowiło twierdzenie, iż dane wynikające $\mathrm{z}$ wyżej wymienionych raportów zachowują aktualność (niewielka liczba - w porównaniu do relacji z innymi ośrodkami pozaeuropejskimi np. z chińskimi - aktywnych polsko-amerykańskich partnerstw miast), a główną przyczyną opisywanego stanu rzeczy jest niski stopień zainteresowania współpracą obu stron, w tym brak wsparcia ze strony rządowej, zarówno polskiej, jak i amerykańskiej. Szczególnie zasadne wydaje się tu właśnie porównanie polsko-amerykańskiej współpracy miast do analogicznych relacji polsko-chińskich. Zarówno w przypadku USA, jak i Chińskiej Republiki Ludowej mamy do czynienia z globalnymi mocarstwami, znajdującymi się w porównywalnej odległości od Polski. Z pierwszym z tych państw współpraca polskich samorządów rozwija się intensywnie, a $\mathrm{z}$ drugim - wprost przeciwnie.

Artykuł ten podejmuje próbę wypełnienia pewnej luki w literaturze, dotyczącej polsko-amerykańskiej współpracy miast. W zamierzeniu autora to opracowanie stanowi wstęp do dalszych pogłębionych badań jakościowych, które pozwolą na pełniejsze zrozumienie zidentyfikowanych tu sieci powiązań i głównych płaszczyzn współpracy (również na przykładzie wspólnie realizowanych projektów). Dalszej analizy wymaga też proces wyboru partnerów w USA przez polskie miasta. $\mathrm{Na}$ tym etapie badań wiele wskazuje na jego przypadkowość (duże znaczenie nieformalnych powiązań międzyludzkich prowadzących do zawierania umów).

25 Znacząca intensyfikacja współpracy polskich i chińskich samorządów nastąpiła $\mathrm{w}$ drugiej dekadzie XXI w. The subnational dimension of EU-China relations, red. A. Skorupska, J. Szczudlik, PISM, Warsaw, August 2019, s. 24.

26 Dane dostępne w internecie, [dostęp: o9 VII 2021]: <https://www.miasta.pl/uploads/ document/content_file/672/baza_miasta_gminy.pdf $\rangle$. 
Koncentrując się na współpracy międzynarodowej miast, autor wpisuje się w krąg zwolenników analizy wielopoziomowej struktury polityki zagranicznej (obejmującej nie tylko aktywność aktorów narodowych, ale również ponadnarodowych i subpaństwowych ${ }^{27}$, a tym samym dołącza do przeciwników podejścia państwocentrycznego (postrzegającego państwa jako jedyny podmiot stosunków międzynarodowych).

Głównym narzędziem badawczym były ankiety wysłane drogą e-mailową do wszystkich polskich miast, których populacja przekracza 50 tys. mieszkańców i które deklarują na swoich oficjalnych stronach internetowych współpracę z miastami amerykańskimi (najczęściej jest to kategoryzowane jako „miasta partnerskie”, "miasta bliźniacze” bądź „współpraca międzynarodowa"). Dodatkowym źródłem wiedzy były informacje zawarte na wspomnianych stronach internetowych poszczególnych miast oraz na witrynie Związku Miast Polskich ${ }^{28}$, a także wywiady bezpośrednie prowadzone telefonicznie $\mathrm{z}$ urzędnikami miejskimi.

Z grupy 83 największych polskich miast o współpracy z partnerami amerykańskimi informują 23 miasta i to do nich zostały wysłane kwestionariusze badawcze. Odpowiedzi - poprzez wypełnienie ankiety (a w nielicznych przypadkach poprzez rozmowę telefoniczną, z której sporządzano notatkę) - udzieliły wszystkie miasta. Zebrane w ten sposób informacje pozwoliły w 13 przypadkach zidentyfikować współpracę nieaktywną. Za nieaktywną formę współpracy przyjęto w tym badaniu brak realizacji wspólnych projektów na przestrzeni ostatnich dwóch lat. Określenie takiego zakresu czasu - podobnie jak progu populacji powyżej 50 tys. mieszkańców wynikało m.in. z faktu, iż kryteria te stosowane są również we wspomnianej wyżej analizie badaczy z Uniwersytetu Łódzkiego. Dzięki temu możliwe jest porównywanie danych zawartych w obu opracowaniach. Kryteria te, rzecz jasna, mają też praktyczne uzasadnienie. $\mathrm{Z}$ rozmów $\mathrm{z}$ urzędnikami miejskimi zaangażowanymi w kontakty międzynarodowe wynika, iż brak wspólnych działań z partnerem zagranicznym na przestrzeni dłuższej niż dwa lata $\mathrm{z}$ reguły zamienia się w permanentny zanik współpracy.

27 Patrz szerzej: B. Hocking, Localizing foreign policy. Non-central governments and multilayered diplomacy, Palgrave Macmillan UK, London 1993.

28 Wspótpraca miast partnerskich, Związek Miast Polskich, dostępny w internecie [dostęp: 30 IV 2021]: 〈https://www.miasta.pl/strony/wspolpraca-miast-partnerskich〉. 
Dla zaistnienia międzynarodowej kooperacji miast, co podkreślali urzędnicy pytani przez autora, bardzo ważne są osobiste kontakty między stronami. Wieloletnie przerwy w realizacji wspólnych projektów zwiększają prawdopodobieństwo pojawienia się barier w postaci przetasowań kadrowych (zmiana ekipy rządzącej miastem lub rotacja zatrudnionych urzędników), a tym samym przerwania wcześniejszych relacji międzyludzkich, na których bazowało dane partnerstwo.

Omawiane w niniejszym artykule badanie ankietowe zostało przeprowadzone w kwietniu 2021 r., czyli po ponad roku od wprowadzenia w Polsce obostrzeń sanitarnych związanych z pandemią covid-19. Niewątpliwie sytuacja epidemiczna miała pewien wpływ na intensywność współpracy międzynarodowej samorządowców, niemniej w przekonaniu autora, nie można z nią wiązać ewentualnego całkowitego zaniku kontaktów z partnerami zagranicznymi. Współczesne technologie pozwalają bowiem na efektywną komunikację i współpracę na odległość, bez konieczności bezpośrednich spotkań.

Na koniec części wstępnej warto jeszcze dokonać wyjaśnienia terminologicznego. W literaturze przedmiotu, ale również na oficjalnych stronach internetowych poszczególnych miast pojawiają się różne określenia odnoszące się do współpracy miast. W Polsce najczęściej mowa jest o "miastach partnerskich” i „miastach zaprzyjaźnionych”. Rzadziej spotyka się określenie "miasta braterskie”. W Stanach Zjednoczonych natomiast najczęściej używa się terminu "miasta siostrzane” (ang. sister cities) bądź „miasta bliźniacze" (ang. twin towns). Wszystkie te określenia dotyczą sformalizowanej współpracy miast (najczęściej w dziedzinie kultury, edukacji i gospodarki) i są traktowane przez autora jako synonimy. Podobnie rzecz się ma z nazewnictwem oficjalnego dokumentu inicjującego współpracę i podpisywanego przez strony. Zdecydowano się tu nie wdawać $\mathrm{w}$ różnice prawne między „umową, , deklaracją" $i$ „porozumieniem”. W kontekście niniejszego badania ważne jest bowiem ogólne znaczenie dokumentu manifestującego wolę władz miejskich do zawiązania współpracy z zagranicznym partnerem. Jak wynika z rozmów z urzędnikami miejskimi, to właśnie wola polityczna i zaangażowanie partnerów decyduje o powodzeniu danej relacji międzynarodowej, a nie konkretne zapisy formalne.

Niniejszy artykuł składa się z trzech podstawowych części: wstępu (będącego wprowadzeniem w omawianą tematykę) części głównej (stanowiącej omówienie przeprowadzonych badań) oraz zakończenia (na które składa się podsumowanie wniosków płynących ze zrealizowanego projektu badawczego). 


\section{Omówienie wyników badania ankietowego}

Jakich więc informacji dostarcza nam badanie ankietowe przeprowadzone wśród miast współpracujących ze stroną amerykańską? Jak już wyżej wspomniano, aktywne relacje transatlantyckie w ostatnich dwóch latach utrzymywało dziesięć miast. Są to: Białystok (partnerstwo z Milwaukee), BielskoBiała (Grand Rapids), Bytom (Butte-Silver Bow), Gdynia (Seattle, Brooklyn/ Nowy Jork), Jelenia Góra (Tyler), Katowice (Mobile), Lublin (Erie), Opole (Roanoke), Płock (Fort Wayne) i Rzeszów (Buffalo). Ponadto zidentyfikowano 13 miast, które prowadziły taką współpracę w przeszłości, lecz - z różnych względów - nie utrzymują jej obecnie. O powodach zaniechania tej kooperacji będzie jeszcze mowa w dalszej części artykułu. Pełną listę miast zaangażowanych we współpracę ze stroną amerykańską zawiera poniższa tabela. Podano tam również rok zawarcia umów o współpracy.

Tabela 1. Lista miast deklarujących współpracę z miastami amerykańskimi

\begin{tabular}{|c|c|c|c|c|c|}
\hline Lp. & Miasto & $\begin{array}{l}\text { Rok podpisania umowy/ } \\
\text { porozumienia/deklaracji }\end{array}$ & $\begin{array}{l}\text { Współpraca } \\
\text { aktywna } \\
\text { w ostatnich } \\
2 \text { latach }\end{array}$ & $\begin{array}{c}\text { Miasto } \\
\text { partnerskie } \\
\text { w USA }\end{array}$ & Stan \\
\hline 1. & Białystok & 1995 & tak & Milwaukee & Wisconsin \\
\hline 2. & Bielsko-Biała & 1991 & nie & Grand Rapids & Michigan \\
\hline 3. & Bydgoszcz & 1996 & nie & Hartford & Connecticut \\
\hline 4. & Bytom & 2001 & tak & Butte-Silver Bow & Montana \\
\hline 5. & Chełm & 1998 & nie & Knoxville & Tennessee \\
\hline 6. & Częstochowa & 1992 & nie & South Bend & Indiana \\
\hline 7. & Gdańsk & 1990 & nie & Cleveland & Ohio \\
\hline 8. & Gdynia & $\begin{array}{l}1991 \\
1994\end{array}$ & $\begin{array}{l}\text { tak } \\
\text { tak }\end{array}$ & $\begin{array}{l}\text { Brooklyn (dzielnica } \\
\text { Nowego Jorku) } \\
\text { Seattle }\end{array}$ & $\begin{array}{l}\text { Nowy Jork } \\
\text { Waszyngton }\end{array}$ \\
\hline 9. & $\begin{array}{l}\text { Gorzów } \\
\text { Wielkopolski }\end{array}$ & 1993 & nie & Hazleton & Pensylwania \\
\hline 10. & Jelenia Góra & 1991 & tak & Tyler & Teksas \\
\hline 11. & Katowice & 1990 & tak & Mobile & Alabama \\
\hline 12. & Kraków & $\begin{array}{l}1973 \\
2009\end{array}$ & $\begin{array}{l}\text { nie } \\
\text { nie }\end{array}$ & $\begin{array}{l}\text { Rochester } \\
\text { San Francisco }\end{array}$ & $\begin{array}{l}\text { Nowy Jork } \\
\text { Kalifornia }\end{array}$ \\
\hline 13. & Lublin & 1999 & tak & Erie & Pensylwania \\
\hline 14. & Łomża & 1994 & nie & Muscatine & lowa \\
\hline 15. & Nowy Sącz & 1991 & nie & Columbia County & Georgia \\
\hline 16. & Olsztyn & $\begin{array}{l}\text { 1995; odnowienie } \\
\text { współpracy } 2020\end{array}$ & nie & Richmond & Wirginia \\
\hline 17. & Opole & 1994 & tak & Roanoke County & Wirginia \\
\hline 18. & Płock & 1990 & tak & Fort Wayne & Indiana \\
\hline 19. & Poznań & 1991 & nie & Toledo & Ohio \\
\hline
\end{tabular}




\begin{tabular}{l|l|c|c|c|l} 
Lp. & Miasto & $\begin{array}{c}\text { Rok podpisania umowy/ } \\
\text { porozumienia/deklaracji }\end{array}$ & $\begin{array}{c}\text { Współpraca } \\
\text { aktywna } \\
\text { w ostatnich } \\
\text { 2 latach }\end{array}$ & $\begin{array}{c}\text { Miasto } \\
\text { partnerskie } \\
\text { w USA }\end{array}$ & \multicolumn{1}{|c|}{ Stan } \\
20. & Rzeszów & 1975 & tak & Buffalo & Nowy Jork \\
21. & Szczecin & 1992 & nainesville & St. Luis & Floryda \\
22. & Wrocław & 1991 & nie & Charlotte & Północna \\
23. & Zabrolina \\
\hline
\end{tabular}

Źródło: opracowanie własne na podstawie danych ze stron internetowych miast oraz badania ankietowego (kwiecień 2021 r.).

Warto w tym miejscu zatrzymać się przy trzech miastach z powyższej listy (Wrocław, Kraków i Olsztyn), które odmówiły wypełnienia ankiety, wskazując, iż ich przypadek wymyka się „zerojedynkowemu” podziałowi współpracy na: aktywną i nieaktywną. Ich przedstawiciele drogą e-mailową ${ }^{29}$ udzielili informacji, z której wynika, że miasta te miały w planach w ostatnich dwóch - trzech latach realizację wspólnych przedsięwzięć z partnerami z USA. Na przeszkodzie stanęły jednak czynniki obiektywne. W przypadku Wrocławia był to huragan, który we wrześniu 2018 r. dotknął jego miasto partnerskie (Charlotte), uniemożliwiając delegację polskich samorządowców. W 2020 r. pandemia coviD-19 uniemożliwiła natomiast wizytę we Wrocławiu blogerów kulinarnych z Charlotte. Należy tu też odnotować, iż 21 kwietnia br. wiceprezydent Wrocławia Jakub Mazur nagrał krótkie wystąpienie skierowane do członków Komitetu Sister Cities w Charlotte. Zgodnie z informacją otrzymaną z Biura Współpracy z Zagranicą Urzędu Miasta Wrocław miasto to jest w trakcie prac nad nową strategią współpracy z partnerami zagranicznymi - w tym z Charlotte. Podobnie rzecz się ma z Krakowem, który również wskazuje pandemię koronawirusa jako jedną z przyczyn braku kontaktów z partnerami amerykańskimi (Rochester i San Francisco). Ponadto, jak przekazała przedstawicielka Biura Współpracy Zagranicznej w Kancelarii Prezydenta Krakowa, w przypadku tego miasta relacje zagraniczne są mocno zdecentralizowane. $\mathrm{W}$ omawianym czasie mogły być one prowadzone przez instytucje, takie jak np. uczelnie wyższe bądź muzea, i mogło to się odbywać bez udziału urzędu miasta, ale z wykorzystaniem kontaktów stworzonych

29 E-mail z dn. 27.04.2021 r. od p. Niny Lenartowicz-Sokołowskiej z UM Kraków; e-mail z dn. 28.04.2021 r. od p. Anny Borkowskiej z UM Wrocław; e-mail z dn. 29.04.2021 r. od p. Joanny Niżyńskiej z UM Wrocław; e-mail z dn. 19.04.2021 r. od p. Krzysztofa Otolińskiego z UM Olsztyn. 
w ramach partnerstwa miast. Analogicznie jak Wrocław, tak też Kraków ma w planach na najbliższe lata intensyfikację kontaktów zagranicznych, w tym z partnerami amerykańskimi (okazją do tego ma być m.in. pięćdziesięciolecie nawiązania relacji z Rochester). Trzecie z wyżej wspomnianych miast Olsztyn - jest obecnie w trakcie odnawiania kontaktów z Richmond, z którym w połowie lat dziewięćdziesiątych XX w. zawarło porozumienie o współpracy. Dokument ten nie przełożył się na żadne wspólne projekty w kolejnych latach. Według deklaracji władz miejskich ma to się zmienić w ślad za podpisaną w listopadzie 2020 r. umową o współpracy ${ }^{30}$. Do chwili oddania niniejszego artykułu do druku (początek maja $2021 \mathrm{r}$.) nie rozpoczęto jeszcze konkretnych wspólnych działań - stąd w powyższej tabeli Olsztyn został zaszeregowany do miast nieprowadzących aktywnej współpracy w ostatnich dwóch latach.

Patrząc na umiejscowienie w czasie procesu zawierania umów i porozumień o partnerstwie miast, wyraźnie daje się dostrzec jego intensyfikacja na samym początku lat dziewięćdziesiątych $\mathrm{XX}$ w. oraz w połowie tej dekady. Zjawisko to niewątpliwie związane jest ze zmianami ustrojowymi w Polsce po upadku bloku wschodniego - sprzyjającymi kontaktom międzynarodowym - oraz też zapewne z aktywnością pierwszego pokolenia imigrantów politycznych wśród amerykańskiej Polonii. Wydaje się też, że uprawnione jest przypuszczenie, iż $\mathrm{w}$ pierwszych latach transformacji ustrojowej polscy samorządowcy byli żywotnie zainteresowani korzystaniem z wiedzy i doświadczeń swych amerykańskich odpowiedników. $\mathrm{W}$ miarę rozwoju własnej praktyki, ta potrzeba pozyskiwania zewnętrznego know-how zaczęła maleć. Zauważalny jest też spadek liczby podpisywanych umów w latach następujących po wejściu Polski do Unii Europejskiej, kiedy to najwyraźniej uwaga samorządowców była skupiona na nowych możliwościach związanych z tym wydarzeniem. Omawiany trend ilustruje poniższy wykres. Jego zakres czasowy określa pierwsza i ostatnia umowa zawarta przez polskie miasta z partnerami amerykańskimi.

Analizując listę dziesięciu polskich miast prowadzących w ostatnich dwóch latach aktywną współpracę z miastami amerykańskimi, należy odnotować, iż najmniejsze ośrodki miejskie z tej grupy, tj. te o populacji między 50 tys. a 100 tys. mieszkańców, charakteryzują się bardzo niskim odsetkiem kontaktów z USA - tj. tylko $2 \%$ utrzymuje tego typu relacje.

30 Odnawiamy wspótpracę z Richmond, Olsztyn.eu, 2 II 2021, dostępny w internecie [dostęp: 30 IV 2021]: <https://olsztyn.eu/o-olsztynie/aktualnosci/article/odnawiamy-wspprac-z-richmond-13336.html $>$. 


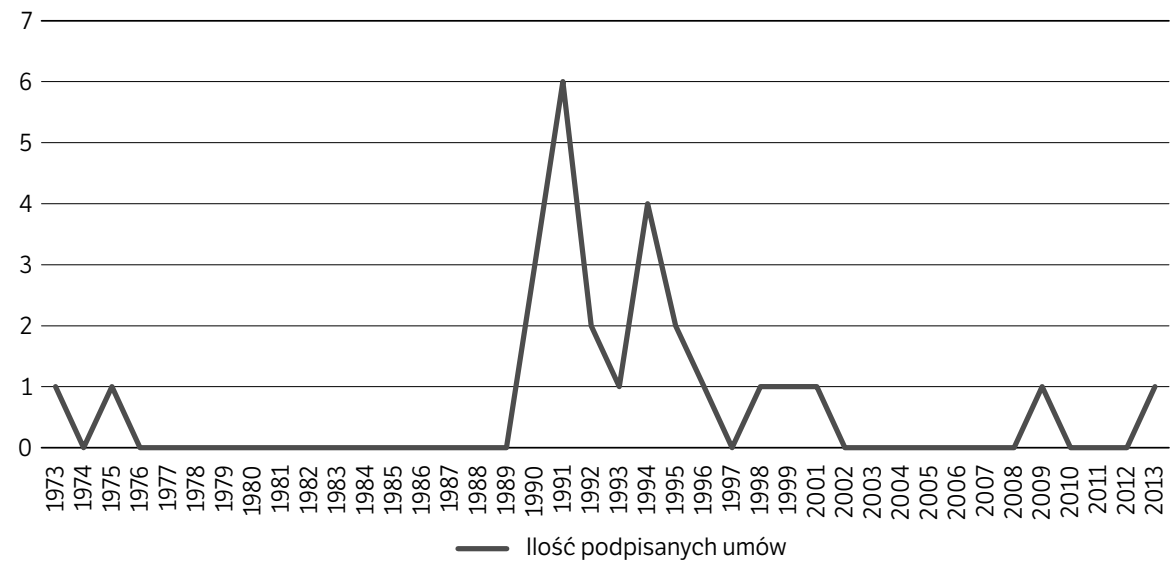

Wykres 1. llość podpisanych umów i porozumień o partnerstwie w latach 1973-2013

Źródło: opracowanie własne na podstawie danych ankietowych (kwiecien 2021 r.) oraz informacji pozyskanych ze stron internetowych miast.

Większa liczba kontaktów obserwowana jest wśród miast średniej wielkości (ti. populacja od 100 tys. do 250 tys. mieszkańców) i dotyczą one $22 \%$ miast tej kategorii. Relacjami z partnerami amerykańskimi może pochwalić największy odsetek miast o populacji od 250 tys. do 500 tys. W tej grupie co drugie miasto utrzymuje takie kontakty. Najbardziej zaskakująca jest tu nieobecność żadnego z pięciu największych polskich miast (populacja powyżej 500 tys. mieszkańców). Niemniej każde z nich - z wyjątkiem Łodzi $^{31}$ - informuje na swych stronach internetowych o podpisanej umowie partnerskiej z miastem w USA.

Tabela 2. Współpraca z amerykańskimi partnerami bądź jej brak w zależności od liczby mieszkańców w polskich miastach

\begin{tabular}{|l|c|c|c|}
\multicolumn{1}{c|}{ Liczba mieszkańców } & Liczba miast & Aktywnie współpracuje & Procent \\
\hline Od $\mathbf{5 0}$ tys. do $\mathbf{1 0 0}$ tys. & 45 & 1 & $2 \%$ \\
\hline Od $\mathbf{1 0 0}$ tys. Do $\mathbf{2 5 0}$ tys. & 27 & 6 & $22 \%$ \\
\hline Od $\mathbf{2 5 0}$ tys. Do $\mathbf{5 0 0}$ tys. & 6 & 3 & $50 \%$ \\
\hline Powyżej $\mathbf{5 0 0}$ tys. & 5 & 0 & $0 \%$ \\
\hline Łącznie (miasta powyżej $\mathbf{5 0}$ tys.) & 83 & 10 & $12 \%$
\end{tabular}

Źródło: opracowanie własne na podstawie danych GUS z 2019 r. oraz badania ankietowego (kwiecień 2021 r.).

31 Miasto Łódź, mimo że aktualnie nie posiada relacji partnerskiej z żadnym z miast w USA, w przeszłości dążyło do nawiązania takiej współpracy, podpisując listy intencyjne z Los Angeles i Atlantą (E-mail z dn. 23.04.2021 od p. Lidii Fazekas z UM Łódź). 
Kwestionariusz badawczy otwierało pytanie dotyczące głównych płaszczyzn współpracy miast polskich i amerykańskich. Jest to niezbędna informacja dla zrozumienia przyczyn partnerstwa miast i ewentualnych oczekiwanych tu korzyści. Wypełniający ankietę urzędnicy miejscy mogli wskazać więcej niż jedną odpowiedź. Dopuszczalne też było udzielenie odpowiedzi spoza gotowych opcji. Dziewięć z dziesięciu badanych miast (tj. Bielsko-Biała, Bytom, Gdynia, Jelenia Góra, Katowice, Lublin, Opole, Płock, Rzeszów) wskazało na „kulturę i sztukę" jako jedną z głównych płaszczyzn współpracy. Kategoria ta obejmuje szerokie spektrum wydarzeń artystycznych, takich jak: współorganizacja lub udział w wystawach (dotyczących zarówno sztuki współczesnej, jak i ekspozycji muzealnych), festiwalach filmowych, koncertach (zarówno popularnej muzyki współczesnej, jak i muzyki ludowej i klasycznej) oraz w występach zespołów teatralnych. Na drugim miejscu pod względem liczby wskazań była kategoria "nauka” (Białystok, Bielsko-Biała, Gdynia, Jelenia-Góra, Lublin, Rzeszów) oraz ex aequo "gospodarka/biznes" (Bielsko-Biała, Gdynia, Jelenia-Góra, Katowice, Lublin, Rzeszów). Najpopularniejszą tu formą współpracy gospodarczej są misje handlowe oraz udział wydarzeniach typu Business Week (np. Gdynia i Seattle). Oba typy aktywności sprowadzają się do tworzenia przez miasta okazji do spotkań przedsiębiorców z obu krajów, które mają doprowadzić do zawiązania współpracy gospodarczej (w postaci intensyfikacji wymiany handlowej oraz inwestycji). Miasta odgrywają tu rolę inicjującą, a ewentualne dalsze kontakty firm odbywają się już bez udziału władz samorządowych. Współpraca naukowa dotyczy głównie szkół wyższych oraz ośrodków badawczych. Jedynie dwa miasta z dziesięciu (Bielsko-Biała i Płock) wskazały, iż ich współpraca z partnerami z USA prowadzi do zwiększenia ruchu turystycznego. Tylko jedno miasto (Bytom) współpracuje z USA w zakresie ochrony środowiska. Co ciekawe, żaden z badanych ośrodków nie realizuje we współpracy ze stroną amerykańską projektów z zakresu sportu. Przyczyny tego stanu rzeczy wymagają głębszej analizy. Na tym etapie badań można jedynie postawić hipotezę, iż może to być powodowane różną popularnością poszczególnych dyscyplin sportowych w Polsce i w Stanach Zjednoczonych ${ }^{32}$. Niemniej gwoli ścisłości należy odnotować, iż jako jeden

32 Według raportu Sponsoring Monitor (z 2020 r.) i ARC Rynek i Opinia (styczeń 2021 r.) najbardziej popularne dyscypliny sportowe w Polsce to piłka nożna, skoki narciarskie, siatkówka, lekkoatletyka i piłka ręczna (dane za: Polacy kochają sport! 
z przejawów współpracy partnerskiej Gdynia wymienia wizytę lokalnej drużyny koszykarek w Seattle w 2003 r. Wśród jednak wszystkich form kontaktów między tymi dwoma miastami, z których wiele ma charakter cykliczny (np. wspomniany już Business Week), ta jednorazowa inicjatywa sportowa zajmuje pozycję marginalną ${ }^{33}$.

Tabela 3. Główne płaszczyzny współpracy z amerykańskimi partnerami

\begin{tabular}{l|c}
\multicolumn{1}{c|}{ Płaszczyzna współpracy } & $\begin{array}{c}\text { Liczba odpowiedzi } \\
\text { (n*=9) }\end{array}$ \\
1. Gospodarka/biznes. & 6 \\
2. Nauka (np. współpraca szkół wyższych/ośrodków badawczych) & 6 \\
3. Kultura i sztuka & 9 \\
4. Sport & 0 \\
5. Ochrona środowiska & 1 \\
6. Turystyka & 2 \\
7. Inne & 3 \\
${ }^{*}$, "n’ oznaczałączną liczbę uzyskanych odpowiedzi na dane pytanie. & \\
Źródło: opracowanie własne na podstawie badania ankietowego (kwiecién 2021 r.). &
\end{tabular}

W omawianym badaniu ankietowym miasta były również proszone o ocenę znaczenia współpracy z partnerem amerykańskim w skali od 1 do 5 , gdzie 1 oznacza "mało ważna”, a 5 - „bardzo ważna”. Jedno z miast odmówiło odpowiedzi na to pytanie. Wśród pozostałych połowa oceniła znaczenie współpracy na 3 (co można określić jako znaczenie umiarkowane), a jedna trzecia określiła tę współpracę jako bardzo ważną ${ }^{34}$.

Pewnym wskaźnikiem znaczenia współpracy są również dane dotyczące ilości pracowników oddelegowanych $\mathrm{w}$ danym urzędzie miasta

Wyniki badania, Brief.pl, 8 II 2021, dostępny w internecie [dostęp: 30 IV 2021]: <https://brief.pl/polacy-kochaja-sport-wyniki-badania/>). W USA natomiast największym zainteresowaniem cieszą się: futbol amerykański, koszykówka, baseball, piłka nożna oraz hokej (dane z 2017 r. za Sports, Gallup.com, [dostęp: 30 IV 2021], dostępny w internecie: 〈https://news.gallup.com/poll/4735/sports.aspx>).

33 Biuletyn Informacji Publicznej Urzędu Miasta Gdyni, [dostęp: 30 IV 2021], dostępny w internecie: 〈https://bip.um.gdynia.pl/miasta-siostrzane,1760/seattle,341505>.

34 Mając na uwadze dobro relacji międzynarodowych badanych miast, autor zdecydował się w tym przypadku nie upubliczniać poszczególnych odpowiedzi w powiązaniu z nazwami miast. Ponadto wskazanie, które konkretnie miasto jak ocenia współpracę z partnerami amerykańskimi, nie ma tu też uzasadnienia poznawczego w kontekście tematu niniejszego artykułu. 
Tabela 4. Ocena znaczenia współpracy (ocena stopniowana od 1 do 5)

\begin{tabular}{l|c}
\multicolumn{1}{c|}{ Ocena współpracy } & Liczba odpowiedzi $(\mathrm{n}=9)$ \\
1. (mało ważna) & 0 \\
2. (częściowo ważna) & 0 \\
3. (umiarkowanie ważna) & 5 \\
4. (ważna) & 1 \\
5. (bardzo ważna) & 3
\end{tabular}

Źródło: opracowanie własne na podstawie badania ankietowego (kwiecień 2021 r.).

do kontaktów z amerykańskim partnerem. Nie należy tu oczywiście też abstrahować od wielkości miasta. W przypadku większych ośrodków miejskich do dyspozycji jest liczniejsza kadra urzędnicza, co teoretycznie może oznaczać również większe zaangażowanie osobowe w projekty zagraniczne. W praktyce nie zawsze tak się jednak dzieje, bo np. miasto, które podało liczbę aż sześciu osób zajmujących się kontaktami z USA, bynajmniej nie jest największym pośród objętych badaniem. Jest natomiast ośrodkiem, który określił kontakty z partnerem amerykańskim jako bardzo ważne. Zdecydowana większość miast do tej sfery działań deleguje od jednej do dwóch osób (łącznie tak wskazało siedem z dziewięciu miast), a jedno miasto szczyci się zespołem trzyosobowym. Warto tu też odnotować przypadek jednego z urzędów miejskich, gdzie na co dzień relacjami z USA zajmują się dwie osoby, ale przy większych projektach zespół ten jest wzmacniany urzędnikami z innych wydziałów. Podobnie jak przy poprzednim pytaniu, tak i przy tym jedno z miast odmówiło odpowiedzi.

Tabela 5. Ocena znaczenia współpracy

\begin{tabular}{|c|c|}
$\begin{array}{c}\text { Liczba pracowników zajmujących się współpracą } \\
\text { z amerykańskim miastem partnerskim }\end{array}$ & Liczba odpowiedzi $(\mathbf{n}=9)$ \\
\hline $\mathbf{1}$ & 4 \\
$\mathbf{2}$ & 3 \\
$\mathbf{3}$ & 1 \\
$\mathbf{4}$ & 0 \\
$\mathbf{5}$ & 0 \\
$\mathbf{6}$ & 1 \\
\hline
\end{tabular}

Źródło: opracowanie własne na podstawie badania ankietowego (kwiecień2021r.).

Jako inicjatora polsko-amerykańskiej współpracy najczęściej wskazywano urząd miasta (czterech na dziewięciu respondentów, jedno z miast nie udzieliło odpowiedzi). Niewiele mniej, bo trzy na dziewięć miast, wskazało inicjatywę ze strony uczelni oraz organizacji polonijnych. Ta ostatnia 
kategoria podmiotów była podawana w kategorii „inne”, gdzie respondenci wpisywali wariant nieujęty na liście. $\mathrm{W}$ dwóch z dziewięciu przypadków jako inicjatora podawano organizacje kulturalne oraz stronę amerykańską (ale w tym ostatnim przypadku też silny był wpływ Polonii). Relatywnie słaby udział świata kultury w nawiązywaniu samorządowych relacji transatlantyckich może świadczyć o niewielkim zainteresowaniu stron popularyzowaniem działalności artystycznej. Równie niski odsetek wskazań dotyczył partnerów amerykańskich jako inicjatorów nawiązywania współpracy. $\mathrm{Na}$ to pytanie można było odpowiedzieć, wskazując więcej niż jedną opcję. I tak też uczyniła niemal połowa miast (cztery z dziewięciu), co oznacza, że do zainicjowania współpracy dążyło równolegle kilka podmiotów. $\mathrm{W}$ trzech z tych czterech miast były to jednoczesne działania dwóch instytucji. A w jednym przypadku (Rzeszów) - inicjatywa aż czterech podmiotów: urzędu miasta, biznesu (przedsiębiorcy), uczelni, a także strony amerykańskiej.

Tabela 6. Inicjatorzy partnerstwa

\begin{tabular}{l|c}
\multicolumn{1}{c|}{ Inicjatorzy partnerstwa* } & Liczba odpowiedzi $(\mathbf{n = 9 )}$ \\
\hline 1. Urząd miasta & 4 \\
\hline 2. Przedsiębiorcy & 1 \\
\hline 3. Uczelnie & 3 \\
4. Organizacje kulturalne & 2 \\
5. Organizacje sportowe & 0 \\
6. Organizacje zaangażowane w ochronę środowiska & 0 \\
7. Organizacje turystyczne & 0 \\
\hline 8. Strona amerykańska & 2 \\
9. Inni & 3 \\
*odpowiedzi od 1 do 7 dotyczą podmiotów po stronie polskiej. & \\
Źródło: opracowanie własne na podstawie badania ankietowego (kwiecień 2021 r.). &
\end{tabular}

Okazuje się, że zainicjowana raz współpraca staje się atrakcyjna również dla lokalnych podmiotów działających w innych obszarach. Jak wynika $\mathrm{z}$ przeprowadzonych ankiet, $\mathrm{w}$ istniejące już relacje chętnie angażują się nowi partnerzy, upatrując w nich korzyści wynikających z wzajemnej wymiany doświadczeń, wiedzy, technologii itd.

Szczególnie charakterystyczne jest tu zachowanie organizacji kulturalnych, które - jak wyżej wspomniano - nie są specjalnie aktywne na etapie nawiązywania kontaktów partnerskich między miastami, ale efektywnie korzystają ze stworzonej sieci powiązań. Fenomen ten dotyczy siedmiu na dziewięć badanych przypadków. Wysoki poziom zaangażowania 
charakteryzuje tu też zarówno przedsiębiorców, jak i uczelnie (w obu przypadkach w czterech na dziewięć miast). Brak jakiejkolwiek aktywności natomiast jest widoczny ze strony organizacji sportowych i proekologicznych. W kategorii „inne” respondenci wymieniali stowarzyszenia polonijne (w dwóch na dziewięć miast) oraz stowarzyszenia dedykowane współpracy partnerskiej miast (w jednym przypadku). Oprócz nowych członków aktywnie działają również sami inicjatorzy (poza urzędem miasta), co zostało potwierdzone przez pięć $\mathrm{z}$ dziesięciu badanych miast.

Tabela 7. Podmioty zaangażowane w partnerstwo (oprócz urzędu miasta)

\begin{tabular}{l|c}
\multicolumn{1}{c|}{ Podmioty zaangażowane w partnerstwo } & Liczba odpowiedzi $(\mathrm{n}=9)$ \\
\hline 1. Przedsiębiorcy & 4 \\
2. Uczelnie & 4 \\
3. Organizacje kulturalne & 0 \\
4. Organizacje sportowe & 0 \\
5. Organizacje zaangażowane w ochronę środowiska & 1 \\
\hline 6. Organizacje turystyczne & 4 \\
\hline 7. Inni & 4 \\
\hline
\end{tabular}

Źródło: opracowanie własne na podstawie badania ankietowego (kwiecień 2021 r.).

Miasta pytane były również o czynniki sprzyjające podtrzymywaniu relacji. Najczęstszą tu odpowiedzią były wizyty oficjalne, na które wskazało aż siedem z dziewięciu badanych miast. Wynik ten nie jest zaskoczeniem, a wspomniana forma wydaje się być najczęściej realizowaną w ramach wszelakich kontaktów zagranicznych - w podobny sposób odbywa się m.in. współpraca zagraniczna miast polskich z partnerami chińskimi $(96 \%)^{35}$ czy miast niemieckich z partnerami chińskimi $(93,5 \%)^{36}$. Kolejnymi najczęściej wybieranymi formami kooperacji są misje gospodarcze oraz udział w imprezach targowych i konferencjach - ex aequo cztery na dziewięć odpowiedzi. Oprócz tego miasta partnerskie organizują wzajemne wymiany młodzieży oraz realizują wspólne projekty kulturalne. Wartą wspomnienia inicjatywą jest pomoc w tworzeniu programu kształcenia lekarzy przez Uniwersytet Floryda z Gainesville dla nowo otwieranego

35 A. Skorupska, Poland, [w:] The role of regions in EU-China relations, red. T. Kamiński, Wydawnictwo Uniwersytetu Łódzkiego, Łódź 2021, s. 174

36 T. Kamiński, J. Ciesielska-Klikowska, Germany, [w:] The role of regions in EU-China relations, red. T. Kamiński, Wydawnictwo Uniwersytetu Łódzkiego, Łódź 2021, ss. 52-53. 
kierunku lekarskiego na Uniwersytecie Rzeszowskim. Również w ramach tej współpracy organizowane są wymiany naukowe i szkoleniowe lekarzy okulistów, pediatrów, neonatologów, kardiologów, neurologów i chirurgów. Silnie rozwiniętymi relacjami szczyci się także Gdynia, która we współpracy z Seattle organizuje od 2009 r. Gdynia Business Week, będący częścią amerykańskiego programu Washington Business Week ${ }^{37}$, prowadzonego przez Foundation for Private Enterprise Education. Gdynia Business Week jest międzynarodowym projektem skierowanym do uczniów gdyńskich szkół średnich oraz ich amerykańskich rówieśników, którego celem jest popularyzowanie wiedzy ekonomicznej. W $2021 \mathrm{r}$. oferta programu została wzbogacona o dodatkowe profile tematyczne z zakresu ekologii i zdrowia (Clean Energy Week oraz Telehealth/HealthCare Week). Należy jednak zaznaczyć, że nie wszystkie podane tu przykłady kooperacji dotyczą wyłącznie ostatnich dwóch lat. Miasta te inicjatywy traktują jako pewien proces kontynuowany na przestrzeni lat $\mathrm{z}$ różną intensywnością. Jedynie Białystok informuje o zaniku aktywności w kontaktach z miastem partnerskim, natomiast Bytom oraz Bielsko-Biała w ogóle nie wskazały żadnej z odpowiedzi, co również można interpretować jako brak wzajemnych działań w ostatnich latach.

Tabela 8. Formy współpracy między miastami partnerskimi

\begin{tabular}{|c|c|}
\hline Formy współpracy & Liczba odpowiedzi $(n=9)$ \\
\hline Wizyty oficjalne & 7 \\
\hline Misje gospodarcze & 4 \\
\hline Stałe przedstawicielstwo w USA & 0 \\
\hline Stałe przedstawicielstwo amerykańskie w danym mieście & 0 \\
\hline Międzynarodowa sieć miast (np. ICLEI lub UCLG) & 0 \\
\hline $\begin{array}{l}\text { Udział w imprezach targowych, konferencjach, forach } \\
\text { ekonomicznych }\end{array}$ & 4 \\
\hline Udział w delegacjach rządowych & 0 \\
\hline Inne & 5 \\
\hline
\end{tabular}

Źródło: opracowanie własne na podstawie badania ankietowego (kwiecień 2021 r.).

Spośród korzyści wynikających ze współpracy partnerskiej najczęściej przywoływane są wymiany szkolne i uniwersyteckie oraz wymiana doświadczeń - tak deklaruje odpowiednio osiem i siedem z dziewięciu

37 Patrz szerzej: Washington Business Week, [dostęp: 30 IV 2021], dostępny w internecie: 〈https://www.wbw.org/>. 
ankietowanych miast. Wysoko plasuje się również promocja lokalnej twórczości artystycznej, którą wskazała połowa miast. Korzyści gospodarczo-ekonomiczne nie wydają się być tutaj istotne, co jest zaskakujące w kontekście płaszczyzn, na których realizowana jest współpraca, ponieważ obok kultury i sztuki oraz nauki, to właśnie biznes i gospodarka wskazywane były najczęściej. Wyjaśnienie tego paradoksu stanowi zapewne brak systemu monitoringu ilości i efektywności nawiązanych relacji biznesowych.

Tabela 9. Korzyści wynikające ze współpracy miast partnerskich

\begin{tabular}{l|c}
\multicolumn{1}{c|}{ Korzyści ze współpracy } & Liczba odpowiedzi \\
\hline Wymiana doświadczeń & 7 \\
$\begin{array}{l}\text { Ułatwienia dla lokalnych przedsiębiorców } \\
\text { (handlujących z firmami amerykańskimi) }\end{array}$ & 1 \\
\hline Przyciąganie amerykańskich inwestycji & 2 \\
\hline Rozwój turystyki & 1 \\
\hline Promocja lokalnej twórczości artystycznej & 5 \\
Wymiana szkolna/uniwersytecka & 8 \\
\hline Inne & 1 \\
\hline
\end{tabular}

Źródło: opracowanie własne na podstawie badania ankietowego (kwiecień 2021 r.).

W kwestii przeszkód, jakie stoją przed miastami partnerskimi, ankietowani są zgodni i na pierwszym miejscu wskazują odległość geograficzną (siedem z dziewięciu miast) oraz wysokie koszty (sześć z dziewięciu miast), które w dużej mierze wynikają właśnie $\mathrm{z}$ położenia na mapie (koszty podróży służbowych). Oprócz tego barierą jest również niski poziom zaangażowania zarówno ze strony amerykańskiej, jak i partnerów lokalnych. Dla żadnego z miast natomiast nie stanowią problemu ani bariera językowa, ani różnice kulturowe czy polityczno-prawne.

Tabela 10. Przeszkody dla współpracy z partnerami amerykańskimi

\begin{tabular}{|l|c|}
\multicolumn{1}{c|}{ Bariera } & Liczba odpowiedzi $(\mathrm{n}=9)$ \\
\hline Odległość geograficzna & 7 \\
Wysokie koszty & 6 \\
\hline Różnice kulturowe & 0 \\
\hline Bariery językowe & 0 \\
\hline Niski poziom zaangażowania partnerów amerykańskich & 1 \\
\hline Niski poziom zaangażowania partnerów lokalnych & 1 \\
\hline Różnice w systemach politycznych i prawnych & 0 \\
\hline
\end{tabular}

Źródło: opracowanie własne na podstawie badania ankietowego (kwiecień2021 r.). 
Spośród czynników decydujących o powodzeniu współpracy na pierwsze miejsce wysuwa się zaangażowanie strony amerykańskiej, któremu sześciu z dziewięciu ankietowanych nadało najwyższą rangę, uzyskując tym samym 4,6 pkt na 5 możliwych (tabela 10). Drugim decydującym wǵ ankietowanych czynnikiem warunkującym efektywność partnerstwa jest czynne uczestnictwo prezydenta miasta $(4,1 \mathrm{pkt})$. Nie bez znaczenia jest także udział lokalnego biznesu oraz szkół i uczelni wyższych (3,6 pkt), a także podpisanie oficjalnej umowy (3,5 pkt). Raczej bez wpływu pozostaje udział władz wojewódzkich bądź państwowych w relacjach $(2,2 \mathrm{pkt})$, a najmniejsze znaczenie dla polskiej strony ma posiadanie stałego przedstawicielstwa w mieście partnerskim $(1,4 \mathrm{pkt})$.

Tabela 11. Czynniki warunkujące powodzenie współpracy z partnerami amerykańskimi

\begin{tabular}{|c|c|}
\hline Czynnik & $\begin{array}{c}\text { Waga czynnika wyliczona } \\
\text { jako średnia z uzyskanych } \\
\text { odpowiedzi* }\end{array}$ \\
\hline Podpisanie oficjalnej umowy & 3,5 \\
\hline $\begin{array}{l}\text { Posiadanie stałego przedstawicielstwa w mieście } \\
\text { partnerskim }\end{array}$ & 1,4 \\
\hline Zaangażowanie prezydenta miasta & 4,1 \\
\hline Zaangażowanie lokalnego biznesu & 3,6 \\
\hline $\begin{array}{l}\text { Zaangażowanie innych organów władzy na szczeblu } \\
\text { wojewódzkim lub krajowym }\end{array}$ & 2,2 \\
\hline Zaangażowanie szkół i uczelni wyższych & 3,6 \\
\hline Zaangażowanie partnera amerykańskiego & 4,3 \\
\hline Współpraca z rządem RP & 2,2 \\
\hline
\end{tabular}

* Punktacja (waga danego czynnika): 5 -b. ważne; 4 - raczej ważne; 3 - ważne; 2 - raczej nieważne; 1 - całkowicie nieważne.

Źródło: opracowanie własne na podstawie badania ankietowego (kwiecień 2021 r.)

Poza wyżej wymienionymi znacząca jest obecność i zaangażowanie Polonii oraz budowanie więzi z przedstawicielami lokalnej społeczności, np. radnymi, artystami czy aktywistami społecznymi.

Warto też odnotować zjawisko znikomego zaangażowania innych szczebli władzy (wojewódzkiego, rządowego i unijnego) w polsko-amerykańskie partnerstwa samorządowe. Jedynie Rzeszów oraz Katowice prowadzą projekty z partnerami amerykańskimi przy współpracy zewnętrznych jednostek - w przypadku tego pierwszego jest to ścisła współpraca z rządem $\mathrm{RP}$, Katowice natomiast kooperują z władzami wojewódzkimi. Nie zaobserwowano również poziomej współpracy - to jest współdziałania poszczególnych miast na rzecz intensyfikacji samorządowych relacji transatlantyckich. Badane urzędy miast deklarowały też umiarkowany wpływ na współpracę 
zagraniczną regionu oraz znikomy wpływ na działania władz państwowych i unijnych. Dane te świadczą o silnie samodzielnym i indywidualnym podejściu miast do kontaktów ze stroną amerykańską.

Na zakończenie należy jeszcze spojrzeć na przyczyny braku aktywności w kontaktach z USA we wspomnianej grupie 13 miast, które w przeszłości takie relacje utrzymywały. Najwięcej z nich (23\%) jako powód zaniechania realizacji wspólnych projektów podaje brak zainteresowania ze strony amerykańskiej. Dla 15\% ankietowanych miast natomiast odległość geograficzna i związane z tym wysokie koszty podróży (delegacji) są powodem zaprzestania współpracy w ogóle. Taki sam odsetek miast wskazuje na brak wsparcia ze strony administracji rządowej. Wśród innych ograniczeń pojawiają się braki kadrowe, brak wsparcia na szczeblu wojewódzkim, brak zainteresowania współpracą w obrębie urzędu czy też wyczerpanie się formuł wizyt czy wspólnych przedsięwzięć.

Jedynie trzy miasta deklarują chęć nawiązania w przyszłości współpracy z nowym bądź odnowienia jej z dotychczasowym partnerem amerykańskim. Pozostałe $\mathrm{z}$ nich albo takiej współpracy nie planują, albo tez odmówiły udzielenia odpowiedzi, co autor interpretuje jako prawdopodobny brak zainteresowania takimi inicjatywami.

\section{Wnioski}

Podsumowując wnioski płynące z przeprowadzonego badania ankietowego, należy wskazać kulturę i sztukę oraz naukę i biznes jako główne płaszczyzny polsko-amerykańskiej współpracy miast. Zwraca tu też uwagę marginalny udział wspólnych projektów z zakresu rozwoju turystyki i ochrony środowiska, a także niemal całkowity ich brak w dziedzinie sportu. Ponad połowa polskich miast prowadzących aktywną kooperację z partnerami amerykańskimi ocenia jej znaczenie jako umiarkowane, a jedynie jedna trzecia badanych uznaje ją za ważną.

W zdecydowanej większości przypadków inicjatorami współpracy była strona polska - najczęściej były to urzędy miast. Zdarzały się też wspólne inicjatywy kilku polskich podmiotów z udziałem władz miejskich. Jedynie w dwóch przypadkach z propozycją nawiązania współpracy wyszła strona amerykańska, wspierana przez środowiska polonijne.

Polsko-amerykańska współpraca miast przybiera głównie formę oficjalnych wizyt władz miejskich, misji gospodarczych, udziału w targach 
i konferencjach branżowych. Znaczny jest też udział wymian młodzieżowych, wspólnych projektów kulturalnych oraz kooperacji uczelni wyższych. Największe korzyści wynikające $\mathrm{z}$ tego partnerstwa urzędnicy dostrzegają we współpracy w szkolnictwie (zarówno średnim, jak i wyższym), w promocji twórczości artystycznej, a także w wymianie doświadczeń w funkcjonowaniu urzędów po obu stronach Atlantyku. Efekty ekonomiczne w postaci wymiany handlowej i napływu inwestycji nie były szczególnie akcentowane w udzielanych odpowiedziach.

Wśród przeszkód dla nawiązywania bądź utrzymywania współpracy wskazywano głównie odległość geograficzną i związane z tym wysokie koszty kontaktów bezpośrednich, a także niskie zaangażowanie strony amerykańskiej. Wydaje się, że ten ostatni czynnik ma znaczenie rozstrzygające dla efektywnego funkcjonowania partnerstwa. Negatywny wpływ czynnika odległłości geograficznej mógłby być zapewne zminimalizowany przy wsparciu politycznemu (a w ślad za tym - finansowym) dla omawianych inicjatyw ze strony szczebla rządowego - zarówno polskiego, jak i amerykańskiego. Zdaniem urzędników pomoc taka nie jest, niestety, udzielana. To też wyraźnie różni polsko-amerykańskie relacje samorządów od polsko-chińskich, gdzie czynnik odległości geograficznej jest niwelowany przez zaangażowanie i wsparcie strony chińskiej.

Omówiony w niniejszym tekście wstępny etap badań nad polsko-amerykańską współpracą miast potwierdził prawdziwość przyjętej hipotezy o utrzymującym się w ostatnich latach niskim poziomie intensywności tych relacji, powodowanym głównie małym zainteresowaniem stron taką formą współdziałania. Niemniej prezentowane tu wyniki ankiet generują wiele nowych pytań, które mogą stanowić punkt wyjścia do drugiego, bardziej pogłębionego, etapu badań.

\section{Bibliografia}

Acuto M., Global cities, governance and diplomacy. The urban link, Routledge, London 2016.

Alger C. F., The world relations of cities. Closing the gap between social science paradigms and everyday human experience, "International Studies Quarterly" 1990, vol. 34(4).

Ancyparowicz G., Bezpośrednie inwestycje zagraniczne w Polsce po akcesji do Unii Europejskiej, „Zeszyty Naukowe SGGW - „Ekonomika i Organizacja Gospodarki Żywnościowej" 2009, nr 77. 
Barber B., Gdyby burmistrzowie rządzili światem, przeł. H. Jankowska, K. Makaruk, Muza, Warszawa 2014.

Biuletyn Informacji Publicznej Urzędu Miasta Gdyni, <https://bip.um.gdynia.pl/ miasta-siostrzane,1760/seattle,341505>.

Florida R., Narodziny klasy kreatywnej, Narodowe Centrum Kultury, Warszawa 2011.

Fuksiewicz A., Łada A., Wenerski Ł., Współpraca zagraniczna polskich samorządów. Wnioski z badań, Instytut Spraw Publicznych, Warszawa 2012.

Hocking B., Localizing foreign policy. Non-central governments and multilayered diplomacy, Palgrave Macmillan UK, London 1993.

Lin Y.P., The fall of Detroit. A financial economist's point of view, "International Journal of Economics and Finance" 2014, vol. 6, no. 7 .

Odnawiamy współpracę z Richmond, Olsztyn.eu, 2 II 2021, dostępny w internecie [dostęp: 30 IV 2021]: 〈https://olsztyn.eu/o-olsztynie/aktualnosci/article/odnawiamy-wspprac-z-richmond-13336.html $>$.

Ozga M., Wpływ bezpośrednich inwestycji zagranicznych na dysproporcje międzyregionalne w Polsce, "Equilibrium. Quarterly Journal of Economics and Economic Policy" 2009, vol. 3, no. 2.

Pieńkowski M., Rybka-Iwańska K., Miasta globalne i ich znaczenie w polityce zagranicznej, „Studia Politologiczne” 2016, vol. 42.

Polacy kochaja sport! Wyniki badania, Brief.pl, 8 II 2021 [dostęp: 30 IV 2021], dostępny w internecie: 〈https://brief.pl/polacy-kochaja-sport-wyniki-badania/〉.

Priorytety polskiej polityki zagranicznej 2012-2016, Ministerstwo Spraw Zagranicznych, Warszawa, marzec 2012, dostępny w internecie [dostęp: 30 IV 2021]: <https:// www.bbn.gov.pl/download/1/9620/prpol.pdf $>$.

Skorupska A., Dyplomacja samorządowa. Efektywność i perspektywy rozwoju, PISM, Warszawa, marzec 2015.

Sports, Gallup.com, dostępny w internecie [dostęp: 30 IV 2021]: <https://news.gallup.com/poll/4735/sports.aspx>.

Szewczak M., Ganczar M., Jaszczuk P., Raport badawczy na temat „Wspótpraca międzynarodowa miast polskich", Narodowy Instytut Samorządu Terytorialnego, 2016, nr 3 ("Badania i raporty”).

Tavares R., Paradiplomacy. Cities and states as global players, Oxford University Press, New York 2016.

The city as a global political actor, eds S. Oosterlynck i in., Routledge, New York 2018.

The role of regions in EU-China relations, red. T.Kamiński, Wydawnictwo Uniwersytetu Łódzkiego, Łódź 2021.

The subnational dimension of EU-China relations, red. A. Skorupska, J. Szczudlik, PISM, Warsaw, August 2019.

Wspótpraca miast partnerskich, Związek Miast Polskich, dostępny w internecie [dostęp: 30 IV 2021]: 〈https://www.miasta.pl/strony/wspolpraca-miast-partnerskich>.

Zawada D., Walory użytkowe jako czynnik konkurencyjności miasta, „Prace Naukowe Uniwersytetu Ekonomicznego we Wrocławiu" 2012, nr 243. 